
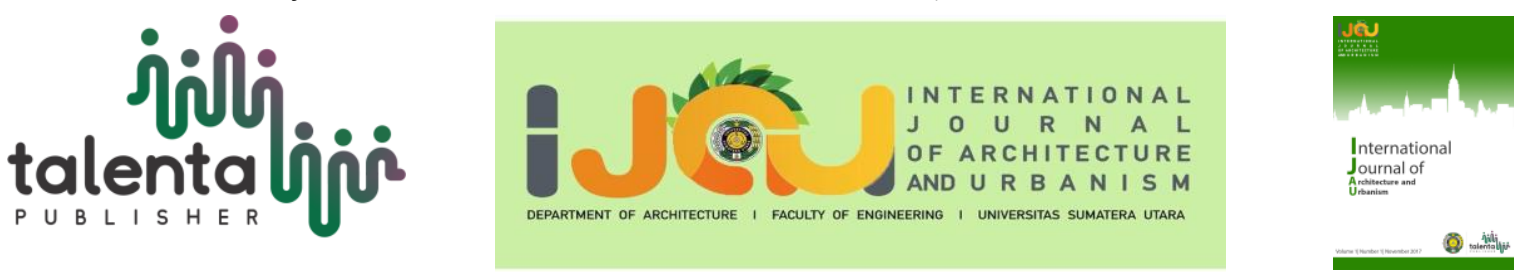

\title{
Urban Settlement Patterns in edge of Railroad in Medan City
}

\author{
Raisha Ghadati Raudina ${ }^{\text {* }}$ \\ ${ }^{1}$ Independent Researcher, Medan, Indonesia
}

\begin{abstract}
As a developing city, Medan City becomes an alternative destination for immigrants who come from various places outside the city of Medan, either for a place to live or earn a living. As a result of this activity, the city of Medan is overgrowing, thus demanding new housing in the form of planned and unplanned settlements. Unplanned settlements arose when the need for housing for newcomers who had a low economy was encouraged. Most of the unplanned settlements became residential spaces built in areas that were not officially planned as residential spaces, such as on railroads' outskirts. The research method used is qualitative because the problem to be studied is social and dynamic. The conclusion obtained from the analysis is that the settlement pattern on the Medan City railroad banks is linear, and settlements grow due to economic, topographic, and infrastructure factors.
\end{abstract}

Keyword: Medan City, patterns of settlements, railroad

Received date month year. | Revised 1 October 2020 | Accepted 15 November 2020

\section{Introduction}

The development of urban areas in Indonesia has always been approached from sectoral and spatial aspects. The sectoral aspect study states the size of the community activities of an urban area in managing its natural resources. The development of residential areas is very vulnerable to uncontrolled development. The high demand for housing without being matched by the availability of adequate land for residential development has led to the development of residential areas as one of the contributors to the urban sprawl phenomenon. Besides, many development problems also arise from residential areas, namely illegal housing and slum settlements, which often impact increasing levels of community inequality, high rates of crime, and low levels of public health. In connection with the many development problems that arise from residential areas' development, the residential area is one of the areas that need special handling. The pattern of settlement distribution is influenced by variations in land use,

\footnotetext{
*Corresponding author at: Independent Researcher, Medan, Indonesia.

E-mail address: raisharaudina@gmail.com
} 
topographic conditions, altitude and area accessibility factors, socio-economic conditions of the population, and socio-economic facilities, which will significantly affect the pattern and spread of settlements area.

Medan City is one of the cities in Sumatra, which is the capital of North Sumatra Province. As a developing city, Medan City is an alternative destination for migrants from various places outside Medan City, either as a place to live or earn a living. As a result of this activity, the population in Medan City is overgrowing. It demands the construction of new residential areas in the form of planned settlements and Real Estate property businesses, which are the solution to the increasing demand for housing. Because basically, Medan City needs houses, apartments, shopping centers, and other commercial spaces to do business based on the limited land in the city center.

With a population of 2.2 million, Medan is the fourth most populated city in Indonesia, after Jakarta, Surabaya, and Bandung, making it the country's biggest city beyond Java Island. Medan is a multicultural metropolis and a busy trading city bordered by the Strait of Malacca. A gateway to the western part of Indonesia, Medan is supported by the Port of Belawan and Kualanamu International Airport, connected to the city center via toll roads and railways [1]. This study aims to identify the distribution patterns of settlements along the Medan City railway. So that in the future, it is expected to be able to provide knowledge about the distribution of settlements along the Medan city railway and as a material for consideration in determining policies and controlling settlements along the Medan City railway.

\section{Literature Review}

\section{Settlement}

A settlement is a place where humans live, which shows a specific purpose. Settlements already provide comfort to its residents (including people who come to the place). When examined in terms of meaning, the settlement comes from translating the word human settlement, which implies a settlement process. The word settlement contains a time dimension in the process [2].

The definition of settlement according to Law no. 1 of 2011 Article 1 concerning housing and settlement areas, settlements are part of a residential environment consisting of more than one housing unit which has the infrastructure, facilities, public utilities, and has supporting activities for other functions in urban or rural areas [3]. The house is a building where humans live and carry out their lives. Housing is a group of houses. Every housing has its value system and habits that apply to its citizens. This value system differs from one housing to another, depending on the area or local community conditions [4]. 
A settlement is a combination of natural, human, and community elements and artificial elements in the form of shade and networking [5]. The house is an integral part of the settlement and is not a physical product at once but is a process that continues to develop and is related to its inhabitants' economic mobility within a certain period. Therefore, the most important thing about the house is the impact on the occupants, not their form and physical standards [6].

\section{Unplanned Settlements}

Settlements that are not planned arise with the need for shelter. Moreover, most of the unplanned settlements become residential spaces built in areas not officially planned as residential spaces. The construction of informal settlements and continues to grow due to the social aspects of these residents. These aspects are carried out from the place of origin where the residents live. The financial influence of this process and the high value of the formal real estate market are among the factors that influence the growth of unplanned settlements [7]. The physical development of informal settlements in patterns, circulation, and locations is established mainly in the social dimension. On the other hand, analysis of physical forms such as roads, plots, and building patterns can estimate the direct impact on social relations. In unplanned settlements, the social conditions of the residents are very influential in forming settlements. The most prominent characteristic of unplanned settlements is the low quality of houses that do not have adequate infrastructure and social facilities [8]. Every residential activity requires a specific space to interact with. Residents can also connect the space needed according to their needs and to support their daily activities.

The economic aspect is one of the factors that influence the development of unplanned settlements. In fulfilling the economic aspect, there has been an increase in migration to urban areas. Migration is generally carried out to improve the economic conditions that can be obtained in big cities. Immigrants who hoped for a better life would need space to live in. Meeting the need for a place to live will be manifested by looking for a residential area that feels suitable for their economic capacity. Besides, movement between residents also allows creating spaces for economic interaction in the region [9]. The interactions between residents often create a need for mutual benefits; thus, this interaction space supports the population's economic activities in the region.

Informal settlements form a similar pattern and pay attention to proximity to public services, work, and housing. They are usually located in locations according to aspects such as considering penetration into the narrower residential streets, which remain protected from strangers. The distance between the three elements: work, public services, and homes, are accessible on foot. The pattern formed, namely, the pedestrian road from the commercial area to the residential road without being disturbed by extensive vehicle traffic routes is a significant factor [10]. 
The road at an unplanned settlement takes many dimensions beyond just connecting two spaces. They work as social centers. Residential orders emerged as noted above due to residents' social needs, which added value to the efficiency of road functions and provided support to become the core of activities in the district. The width of the road is made according to the relationship of the residents and how many residents they want to interact with, and what kind of activities they want to propose on the road. As a result, roads are created efficiently with patterns to meet social and economic aspects. By tracing these roads, it was clear that most of the residential roads had a narrow width that restricted foreigners' access to the area and controlled traffic penetration. Also, they allow several activities, namely the street as a house, the street as an expanded workspace, the street as an expanded cafe, the street as an extended place of celebraTherroad's width as a place to play [11].

In urban areas, the unavailability of adequate housing has resulted in the growth of slums and semi-slums, creating various socio-economic problems. Besides that, the population's density in the city will result in the inadequacy of housing facilities such as roads and other infrastructure. One of the main problems hindering housing development in urban areas is the lack of available land ready to be built and the increasing land acquisition and difficulties in land acquisition for housing. Land use policy in urban areas (urban and policy) is still not supported by adequate legislation [12]. The provision of RTH (Green Line) on the railroad tracks' border is RTH, which has the primary function of limiting the interaction between community activities and railroads. In this regard, it is necessary to determine the railroad borderline's width in urban areas [13].

Public land is an asset that belongs to the urban population and should be utilized by that population. Unfortunately, today, government-owned land tends to be seen as a marketable commodity rather than land for the common good, so sales or rentals are often awarded to the highest bidder for shopping centers, parking lots, luxury hotels, and golf courses instead of city parks, schools, playgrounds, people's markets, and cheap housing that our cities need. One surefire way to reduce the cost of land for housing for low-income people is to use public land, which can be leased by the government agency that owns it or designated as usable land for low-income community housing. This can be planned and developed using various strategies and forms of partnership [14].

\section{Urban Settlement Pattern}

Based on appearances of city morphology and the type of area distribution existing city, Hudson in Yunus (1999) suggested several alternative city shape models. There are six pieces of a city shape model suggested: satellite and neighborhood plans, stellar or radial plans, circuit linear or ring plans, beaded linear plans, the core or compact plans, and dispersed city plans (Figure 1). 


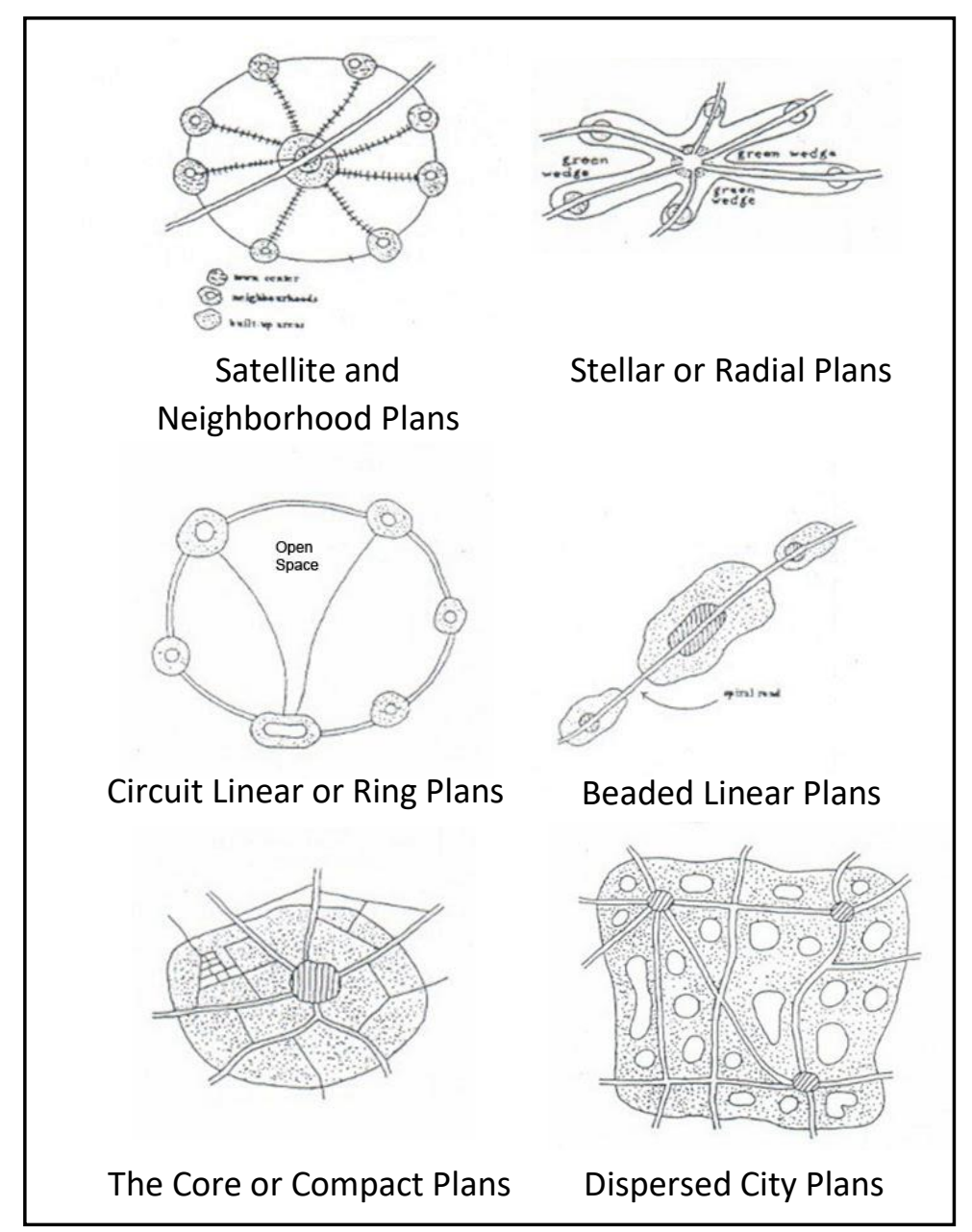

Figure 1 Urban Settlement Pattern

Growth of Settlements along the Railroad

The leading causes of the growth of slum environments are high urbanization and migration, especially for low-income groups of people, difficulty finding work, and difficulty in paying for installments or renting a house. There are three main factors that most influence slum areas along the railroad tracks [15].

The first factor is the factor of building ownership status. The status of building ownership affects how the population views the quality of the housing they live in. The residents who live in slum areas along the railroad tracks that their occupancy is temporary, non-permanent housing. Residents are reluctant to repair the shelter, causing housing quality to decline over time, resulting in a slum environment [16].

The second is economic factors. The low level of income is seen based on the population's ability to make improvements to their housing. The number of low-income people (MBR) in slum areas along the railroad tracks is largest than in other slum areas. Thus, they are causing these low-income residents to be thoughtless and due to poor conditions, ultimately forcing them to build shelters along the railroad tracks whose existence is not under the planned 
settlement space pattern. This can increasingly affect the slums of the residential environment. Housing that is built on land that is not following with this designation has a non-permanent building condition and does not have a building ownership status so that residents who live in areas along the railroad tracks are reluctant to maintain the quality of their housing and environment because they feel they do not have this shelter. As a result, the area where they live becomes dirty and slum because they maintain cleanliness and care for the environment where they live is still low.

The third priority factor is the spatial factor. Spatial factors that can affect the existence of slum areas are due to a lack of understanding of spatial planning. These three factors are the factors that most influence the existence of slum areas along the railroad tracks [17].

\section{Methodology}

The research method used is qualitative because the problem to be studied is social and dynamic. According to Sujarweni (2014), the primary purpose of qualitative research is to understand social phenomena or symptoms by explaining in the form of a clear depiction of these social phenomena or symptoms in the form of a series of words that will eventually produce a theory [18]. Qualitative research aims to understand phenomena holistically and descriptively in the form of words and language in a particular natural context and by utilizing various scientific methods [19].

This study aims to find the typology of settlements in the railway area of Medan City. The method used is qualitative. The research was conducted by observing the research location. In determining the research location, the location studied follows the problem formulation. Namely, the location is a settlement that grows on the railway's outskirts in Medan City.

\section{Result and Discussion}

The The locations in the study are settlements along the Medan City railway. Located in the central part of Deli Serdang Regency, Medan is surrounded by satellite cities and towns such as Binjai, Lubuk Pakam, Tanjung Morawa, Tembung, Percut Sei Tuan, and Labuhan Deli, which help the city become a new urban area in Indonesia which known as 'Mebidang' (Medan, Binjai, Deli Serdang) [20]. Medan City is an area of $265.1 \mathrm{~km}^{2}$, with a population of 2,210,624. Medan City consists of 21 Districts that form it (Figure 2). 


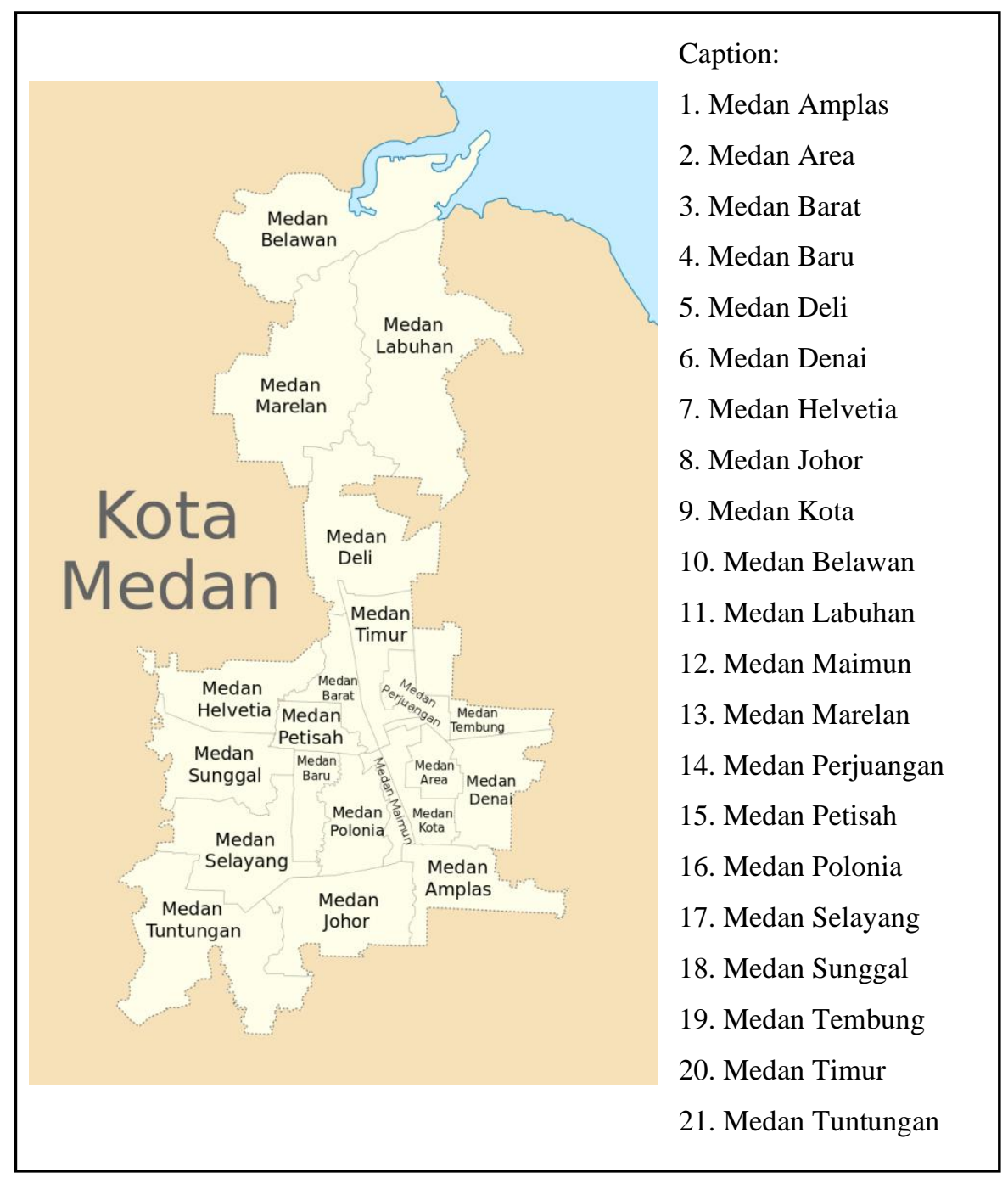

Figure 2 District division of Medan

Settlement Patterns in Edge of Railroad

The type of settlement pattern in Medan City is linear along the railroad tracks (Figure 3). For the houses facing directly to the street, they will follow the direction of the road. Meanwhile, settlements that do not directly intersect with major roads will follow the railroad tracks' direction. This is closely related to the theory of linear settlement patterns, namely settlement patterns that have road, river, mountain, or religious orientation. In this case, the settlement is oriented towards roads and railways. 


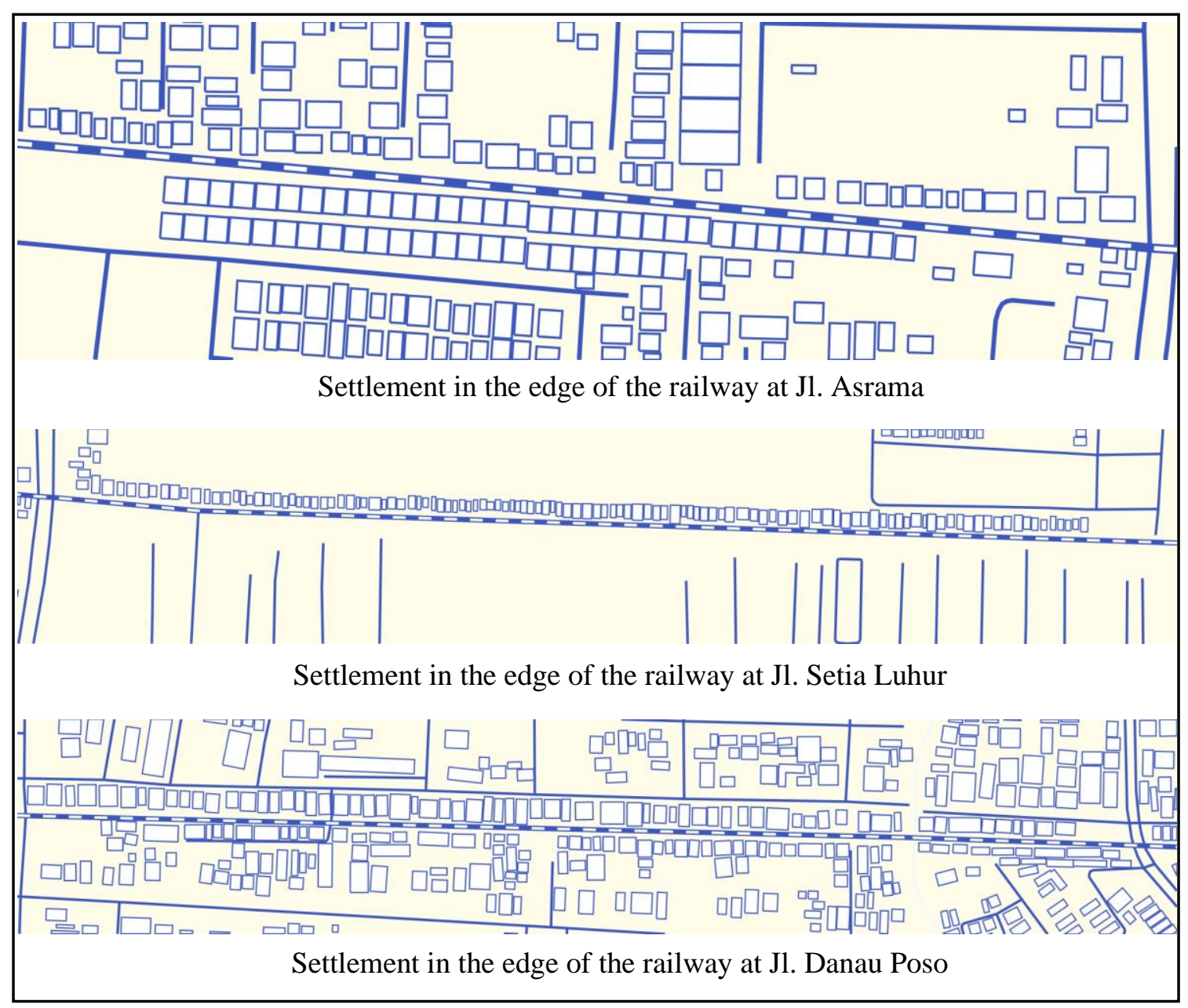

Figure 3 Settlement in the edge of the railway in Medan City

The population growth coming to the city is one of the factors for population growth, likewise with the population increase in settlements along the railway in Medan City. The increase in population and the increasing number of dwellings in residential areas cause residential housing growth. The birth rate, social and economic conditions in the settlements along the railway in Medan City cause population growth. Urbanization, social and economic conditions greatly influence growth. The migrants heading to the railroad banks of Medan City originated from low economic conditions. The high price of land makes immigrants look for cheap land. The migrants use government land to build their houses - the topography of settlements on the banks of the Medan City railway influences forming settlements. The physical form of nature that has been formed from the beginning, namely flat land, has attracted the community's interest to make housing along the railroad tracks. The existing public infrastructure in the settlements along the railway in Medan City also affects the settlements' formation. The community will try to build houses that are close to infrastructure. The closer to infrastructure, the community does not spend much on transportation. 


\section{Conclusion}

The urban area is one area that is attractive to villagers. The urban area is the center of all development. With this development, people flocked to move to the city and formed settlement patterns in the city. We can find linear settlement patterns along the Medan City railway. Linear settlement patterns directly affect interactions between communities. The dense linear settlement pattern that tends to be close to each other reflects the people's high social solidarity. Besides that, the values of togetherness, cooperation, and feeling of themselves as a whole are also reflected. Linear settlement patterns provide opportunities for residents to interact more intensively and openly. Thus, social control can be controlled collectively. Likewise, the relationship of settlement patterns like this seems to be positively correlated with the community's socio-cultural aspects. However, the growth of buildings on the outskirts of the Medan City railroad tracks is influenced by the population's economic background. The factor that influences people to live on the railroad tracks' outskirts is their inability to buy decent, low-income houses. Therefore, it is necessary to carry out a settlement program for low-income people, especially for lands that are not suitable for habitation and have an illegal status to create beautiful cities.

\section{REFERENCES}

[1] "Total Population by Gender and the Regency/City of North Sumatera" Oct. 3, 20017. [Online]. Available: http://sumut.bps.go.id [Accessed: Nov. 1, 2020].

[2] Sastra M., Suparno, and E. Marlina, Housing Planning and Developme. Yogyakarta: ANDI Yogyakarta, 2005.

[3] Law of the Republic of Indonesia Number 1, Housing and Settlement Areas. Jakarta: State Secretariat; 2011.

[4] Budihardjo, and Eko, Housing and Settlements in Indonesia. Bandung: PT. Alumni Bandung, 2009.

[5] B. Ahyat, "Watershed Settlement Study (Case Study: Krueng Langsa)," Postgraduate Thesis, Universitas Sumatera Utara, Medan, 2012.

[6] Batudoka, and Zubair, "New Cities and Future Settlement Aspects," Journal of SMARTek, vol. 3, No. 1, pp.27-36. 2005.

[7] Eldravawi, S., "Impact Of Physical Structure Of Informal Settlements On The Social Integration Of Resident," paper presented at the International RC21 Conference. 2013

[8] Ali, M., H., \& Sulaiman, M., S, "The Causes and Consequences of the Informal Settlements in Zanzibar," Informal Settlements: Policy, Land Use, and Tenure. 2006.

[9] Mohamed, A, A., \& Mohareb, N. "Social Networks in the space of unplanned settlements in Cairo metropolitan area. SS10 Proceedings of the $10^{\text {th }}$ International Space Syntax Symposium. London, UK, 2015.

[10] B.O.Y. Marpaung, and B. P. B. Sembiring, "Settlement Forms on the Deli River, Medan Labuhan District," Journal of IPLBI, vol. 12, A, pp.017-028. 2019. 
[11] Eldravawi, S., "Impact Of Physical Structure Of Informal Settlements On The Social Integration Of Resident," paper presented at the International RC21 Conference. 2013

[12] Budihardjo, and Eko, Housing and Settlements in Indonesia. Bandung: PT. Alumni Bandung, 2009.

[13] Regulation of the Minister of Public Works, N0. 05/PRT/M/2008, Provision and Utilization of Green Open Space in Urban Areas, 2008.

[14] Sumarwanto, "The Influence of Low-Income Communities and Slum Settlements on Regional Spatial Planning in Semarang," Scientific Journal of Serat Acitya, UNTAG Semarang, 2014.

[15] M. Krisandriyana, W. Astuti, and E. Fitriarini, "Factors Affecting The Existence of The Area Slum Settings in Surakarta," Journal of Desa-Kota, vol. 1, no. 1, pp.24-33. 2019.

[16] Surtiani, "Factors Affecting the Creation of Slum Area in the City Center Area (Case Study: The Shower Area, Salatiga)," Semarang, 2006.

[17] M. G. Rindarjono, Slum Study of Slum Settlement in a Spatial Perspective. Yogyakarta: Media Perkasa, 2013.

[18] Sujarweni, and V. Wiratna, Research Methodology. Jakartaa: Pustaka Baru Press, 2014.

[19] Moleong, and Lexy J., Qualitative Research Methodology (Revised Edition). Bandung: PT. Remaja Rosdakarya, 2014.

[20] "Medan" in Wikipedia, 2015. [Online]. Available: http://en.wikipedia.org/wiki/Medan [Accessed: Nov. 1, 2020]. 